\title{
Approaches for Diagnosis of Avian Infectious Bronchitis
}

\author{
S. Shekhar ${ }^{1}$, S.B. Sudhakar ${ }^{2 *}$, A. Kumar ${ }^{3}$ and S. Kumar ${ }^{4}$ \\ ${ }^{1}$ KrishiVigyan Kendra, Koderma, Jharkhand, India \\ ${ }^{2}$ ICAR-National Institute of High Security Animal Diseases, Bhopal, India \\ ${ }^{3}$ ICAR- Indian Veterinary Research Institute, Bareilly, India \\ ${ }^{4}$ Bihar Veterinary College, Patna, India \\ *Corresponding author
}

\section{A B S T R A C T}

\section{Ke ywords \\ Avian infectious bronchitis, \\ Coronavirus, \\ Poultry, Diagnosis, \\ Serology, Virus \\ Isolation, Molecular \\ Methods \\ Article Info \\ Accepted: \\ 04 August 2019 \\ Available Online: \\ 10 September 2019}

Avian infectious bronchitis (IB) is one of the major economically important, worldwide distributed and highly contagious and acute upper- respiratory tract disease of poultry caused by avian infectious bronchitis virus (IBV) belonging to family Coronaviridae and affects both galliform and nongalliform birds. IBV demonstrates a wide range of tissues tropism, including the renal and reproductive systems. The clinical outcome of the infection in chickens depends on many variables such as the virus strain and type; sex and age of the chicken; immune status; co- infections; and environmental circumstances. Effective diagnostic tools are required to diagnose IB infections in field and to identify different serotypes and variants. Diagnosis of IB is done based on the clinical history, lesions, serological investigation, virus isolations and antigen detection. Current methods, such as reverse transcription polymerase chain reaction (RT-PCR), Restriction Fragment Length Polymorphism (RFLP) and sequencing offer highly sensitive, rapid, and accurate diagnostic results within the shortest possible time. This review discusses on approaches for diagnosis of avian infectious bronchitis infection.

\section{Introduction}

Infectious bronchitis (IB), an important respiratory disease of chickens, is characterized by increased oculo-nasal secretion and excess mucus in the trachea accompanied by decreases in both weight gain and feed efficiency (Ignjatovic and Sapats, 2000). The virus also replicates in the oviduct and testes of infected birds resulting in reduced egg production and fertility (Cavanagh and Naqi, 2003; Boltz et al., 2004) Moreover, some IBV strains can infect the kidney causing significant mortality (Cook $e t$ al., 2001). The establishment of persistent infections in chickens has also been reported (Jones and Ambali, 1987). It is of major economic importance because IB is a cause of poor weight gain and feed efficiency, a component of mixed infections that produce air sacculitis which may result in condemnations broilers processing and a cause of egg-production and egg-quality declines (Cavanagh and Naqi, 2003). Mortality in broilers often peaks commonly at five to six weeks of age. Death itself is 
usually caused by secondary bacterial infection, the bacteria becoming systemic following damage to the respiratory tract. Some strains of the virus are highly nephropathogenic, with the potential to cause mortality up to $30 \%$ in young birds (Cavanagh and Gelb, 2008; Ariaans et al., 2008; Gallardo et al., 2012).Losses from production inefficiencies are usually of greater concern than losses from mortality. Infectious bronchitis was first observed in the United States in North Dakota in 1930 (Schalk and Hawn, 1931). Initially, IB was recognized as primarily a disease of young chicks, however, it was later observed to be common in semi-mature and laying flocks (Cavanagh, 2007). Infectious bronchitis is distributed worldwide (Cavanagh, 2007; Arshad, 2006). In the United States, several serotypes in addition to the originally identified Massachusetts (Mass) type of IBV were identified, beginning in the 1950s. Many other serotypes, distinct from those in North America, have also been isolated in Africa, Asia (e.g., China, India, Japan and Korea); Australia; and Europe. Outbreaks of IB frequently occur, even in vaccinated flocks. The virus strains isolated from those outbreaks are often, but not always, found to be a serotype distinct from the vaccine type.

\section{Etiology}

The enveloped infectious bronchitis virus (IBV) is classified in the order Nidovirales, family Coronaviridae, and it is the type species of the genus Coronavirus(Cavanagh and Naqi, 2003).Serotype or genotype classification of IBV is based on features of the $\mathrm{S}$ protein. Traditionally, IBV serotypes have been defined by VN tests, VN antibody being induced by the $\mathrm{S} 1$ subunit of the $\mathrm{S}$ protein. Infectious bronchitis virus is round to pleomorphic in shape. It possesses an envelope that is approximately $120 \mathrm{~nm}$ in diameter with club-shaped surface projections (spikes) about $20 \mathrm{~nm}$ in length (Davies and Macnaughton, 1979; Cavanagh and Naqi, 2003; Cavanagh, 2005). Ribonucleo-protein (RNP, core) structures released from spontaneously disrupted particles could be visualized by shadowing but not by negativestaining. Infectious bronchitis virus contain three major structural proteins: the spike(S) and membrane $(\mathrm{M})$ glycoproteins and the internal nucleoprotein $(\mathrm{N})$ protein (Cavanagh and Naqi, 2003).In addition, a fourth protein (small membrane protein, E) is believed to be associated with the virion envelope in very small amounts ;it is essential for virus particle formation(Corse and Machamer, 2003; Wilson et al., 2006). The S protein comprises two or three copies of each of two glycopolypeptides, S1 and S2 (approximately 520 and 625 amino acids, respectively) (Cavanagh, 1983; Adzar et al., 1997; Capua et al., 1999; Cavanagh and Naqi, 2003). Only about $10 \%$ of the $\mathrm{M}$ protein is exposed at the outer virus surface (Wadey and Faragher, 1981; Cavanagh, 1983). The $\mathrm{N}$ protein is around the single piece of single-stranded, positive sense, RNA genome (to form the RNP). Moststrains of IBV are inactivated after 15 minutes at $56^{\circ} \mathrm{C}$ and after 90 minutes at $45^{\circ} \mathrm{C}$ (Cavanagh and Naqi, 2003). Infected tissues stored in 50\% glycerol are well preserved, and tissues in this medium can be shipped to the laboratory for diagnosis without refrigeration (Cavanagh and Naqi, 2003). Infectious allantoic fluid lyophilized, sealed under vacuum, and stored in a refrigerator has remained viable for at least 30years. Ten percent glucose gives a stabilizing effect to IBV in the lyophilized and frozen states. Infectious bronchitis virus is ether labile, but some virus survived $20 \%$ ether $\left(4^{\circ} \mathrm{C}, 18\right.$ hours). All infectivity was destroyed by $50 \%$ chloroform (room temperature, 10 minutes) and $0.1 \%$ sodium deoxycholate $\left(4^{\circ} \mathrm{C}, 18\right.$ hours $)$. Infectious bronchitis virus is considered to be sensitive to the common disinfectants. Treatment with 
a final concentration of 0.05 or $0.1 \%$ betapropiolactone (BPL) or $0.1 \%$ formalin eliminated IBV infectivity (Cavanagh et al., 1999).

\section{Disease}

Infectious bronchitis virus spreads rapidly among chickens in a flock. Re-excretion of IBV has also been detected from hens that had been virus-negative for several weeks following recovery from inoculation atone day of age. The nature of the persistence of IBV infection remains undefined, although the kidney may be one of the sites of persistent infection (Alexander and Gough, 1977). Reports of extended and intermittent shedding are evidence ofthe potential risk of flock-to-flock transmission via contamination of personnel or equipment (Hofstad, 1984; Cavanagh and Naqi, 2003). All ages are susceptible, but the disease is most severe in baby chicks, causing some mortality. As age increases, chickens become more resistant to the nephritogenic effects, oviduct lesions, and mortality due to infection (Crinion and Hofstad, 1972). The incubation period is 1836 hours, depending on dose and route of inoculation (Cavanagh and Gelb, 2008). Chickens exposed to an aerosol of undiluted infective egg fluid regularly have tracheal rales within 24 hours. Naturally occurring spread requires about 36 hours or more. The characteristic respiratory signs in chicks are gasping, coughing, sneezing, tracheal rales, and nasal discharge (Cavanagh and Gelb, 2008). Wet eyes may be observed, and an occasional chick may have swollen sinuses. The chicks appear depressed and may be seen huddled under a heat source. Feed consumption and weight gain are significantly reduced. In chickens greater than 6 weeks of age and in adult birds, the signs are similar to those in chicks, but nasal discharge does not occur as frequently, and the disease may go unnoticed unless the flock is examined carefully by handling the birds or listening to them at night when the birds are normally quiet. In laying flocks, decline in egg production and quality are seen in addition to respiratory signs. The severity of the production decline may vary with the period of lay and with the causative virus strain. In addition to production declines, the number of eggs unacceptable for setting is increased; hatchability is reduced; and soft-shelled, misshapen, and rough-shelled eggs are produced. The albumen may be thin and watery without definite demarcation between the thick and thin albumen of the normal fresh egg (Cavanagh, 2007; Winterfield et al., 1984). Infected chickens have serous, catarrhal, or caseous exudate in the trachea, nasal passages, and sinuses. Air sacs may appear cloudy or contain a yellow caseous exudate. A caseous plug may be found in the lower trachea or bronchi of chicks that die. Small areas of pneumonia may be observed around the large bronchi. Nephropathic infections produce swollen and pale kidneys with the tubules and ureters often distended with urates (Boroomand et al., 2012; Cong et al., 2013). Fluid yolk material maybe found in the abdominal cavity of chickens that are in production, but this is also seen with other diseases that cause a marked drop in egg production (Winterfield and Hitchner, 1962; De Wit et al., 2011). Permanent lesions in the oviduct may be a consequence of IBV infection of one-day-old chicks and are a cause of reduced egg production (Chousalkar and Roberts, 2007; Chousalkar et al., 2007)

\section{Diagnosis}

Infectious bronchitis virus (IBV) is a major cause of economic losses in poultry and can be involved in respiratory disease, nephritis, and both poor egg production and quality. However, the signs are not specific to IBV. Infectious bronchitis may resemble other acute respiratory diseases such as Newcastle 
disease (ND), Laryngotracheitis and Infectious Coryza. Newcastle disease is generally more severe than IB. Nervous signs may be observed with virulent strains of ND and in laying flocks, drops in production may be greater than with IB. Laryngotracheitis tends to spread more slowly in a flock, but respiratory signs may be more severe than with IB. Infectious coryza can be differentiated on the basis of facial swelling that occurs only rarely in IB. Production declines and shell quality problems in flocks infected with the egg drop syndrome (EDS) adenovirus are similar to those seen with IB, except that internal egg quality is not affected in the case of EDS (Sylvester et al., 2005; Cavanagha and Gelb, 2008). Therefore, diagnostic tools are needed to identify IBV infections in relation to a clinical problem in the field. Diagnosis of IB is based on the clinical history, lesions, seroconversion or rising IBV antibody titers, IBV antigen detection by a number of antibody based assays, virus isolation and more recently, by detection of IBV RNA (Pradhan et al., 1982; Verma and Malik, 1971; Sylvester et al., 2003a; Dhama et al., 2011). Diagnosis should include, if possible, identification of the serotype orgenotype of the virus because of the great antigenic variation exhibited by IBV strains and the availability of vaccines designed for different serotypes. In general, acute IBV infections can be diagnosed by detection of IBV virus (antigen) itself or the specific antibody response. The most common assays for routine use of virus detection are virus isolation (VI), immunofluorescence assay (IFA), immunoperoxidase assay (IPA), polymerase chain reaction (PCR), and for antibody detection the haemagglutination inhibition (HI) test, agar gel precipitation test (AGPT), and enzyme linked immunosorbent assay (ELISA). The level of success in detection of IBV after a disease outbreak is influenced by many factors of which the time between onset of infection and sampling, the level of immunity in the chicken at the moment of infection, and the number, choice and quality of sampled organs are the most important. Time elapsed between onset of infection and sampling. The upper respiratory tract is the primary site of IBV replication, leading to viraemia and dissemination of the virus to other tissues. All IBV strains can be isolated from the respiratory tract, with the highest concentration of IBV in thetrachea during the first 3 to 5 days after infection. After this period, thevirus titre drops rapidly in the second week post infection to below the detection level. When chickens are sampled in the chronic stage of an IBV infection, one is more likely to isolate IBV from the intestinal tract (caecal tonsils or cloaca swabs) than from the trachea.

\section{Virus isolation}

The trachea is a primary target for IBV and is, therefore, a preferred sampling site, especially within the first week of infection. The sample could be either tracheal swabs or tracheal tissue collected at postmortem. Cloacal swabs or cecal tonsils collected during post mortem examination, however, can be of particular value in cases in which more than one week may have elapsed since the start of infection(Gelb et al., 1998). The virus grows initially in the upper respiratory tract and spreads to nonrespiratory organs. Consequently, the virus generally is cleared from the trachea sooner than from the intestinal tissues. Samples from the lungs, kidneys, and oviduct should also be considered depending on the clinical history of the disease. Samples for virus isolation commonly are inoculated into embryonated chicken eggs or tracheal organ culture s(Colwell and Lukert, 1969; McMartin, 1993). Most isolates of IBV replicate well in the developing chicken embryo following inoculation of the allantoic cavity; high titers 
of virus can occur in the allantoic fluid (Beaudette and Hudson, 1937;Clarke et al., 1972; Cavanagh and Naqi, 2003). Dwarfing of a few embryos with survival of $90 \%$ through the $19^{\text {th }}$ day of incubation is characteristic of IBV field material upon initial inoculation in 10 to 11 day-old embryonated chicken eggs, although some isolates do not cause dwarfing after three passages (Loomis et al., 1950). Tracheal rings are prepared from 20-day old embryos and maintained singly in roller tubes. Following infection with IBV, ciliostasis, which is easily observed by low-power microscopy, occurs within 3-4 days. Tracheal organ cultures have proved very successful for the isolation, titration and serotyping of IBV, because no adaptation of field strains is required for growth and the induction of ciliostasis (Jones and Hennion, 2008). Fluids should be harvested after 48-72 hours from either culture system for blind passage into another set of cultures. Each sample should receive at least four blind passages before being called negative based on failure to cause embryo death, lesions, or ciliostasis in the organ cultures. These observations are not in themselves sufficient to confirm the presence of IBV; the virus presence must be confirmed by ELISA, immunohistochemistry, nucleic acid analysis, or by electron microscopy. Chick embryo kidney (CEK) cells and CK cells have been used most successfully for the study of IBV (Otsuki et al., 1979; Arshad, 1993; Lukert, 1965). Plaquesize and morphology vary among strains; plaque size of most strains is greater at $40^{\circ} \mathrm{C}$ than at $37^{\circ} \mathrm{C}$. CK cells are widely used with many isolates of IBV, and only the Beaudette strain has been used extensively in Verocells. Chicken kidney cells began to form syncytia 6 hours after inoculation with IBV-Beaudette. The nuclei become pycnotic. Syncytia in CK cultures quickly round up and detach from the substrate, appearing as large spheres with the refractile contents eccentrically placed, but syncytia in Vero cells infected with Vero celladapted IBV-Beaudette contain numerous nuclei and remain on the substrates longer. The Beaudette strain has been propagated successfully in a chicken hepatoma cell line $(\mathrm{LMH})$, and in the African green monkey Vero cell line. The M41 and Iowa97 strains of IBV have also been adapted to the mammalian Vero cell line, although subsequent use of these strains in Vero cells has not occurred (Otsuki et al., 1979). Virus isolation (VI) can be laborious, timeconsuming and costly. Increasingly, the classical way of isolation, that is giving a number of embryo passages until dwarfing, curling or embryo mortality occur, is more often replaced multiplication of the virus and a second technique, such as IFA, antigen ELISA or PCR for antigen detection. By using the combination of isolation and other techniques, the procedure can be shortened with maintenance of sensitivity. Field strains of IBV can be isolated using embryonated (SPF) eggs or trachea organ cultures. In none of these systems, IBV causes specific lesions. Therefore, the presence of IBV antigen has to be confirmed by an IBV antigen detection method.

\section{Serology}

Detection of IBV directly using post-mortem material may be attempted. Sections or scrapings of the tracheal mucosa and other tissues taken from birds at postmortem can be examined by immunofluorescence or immunoperoxidase assays, using IBV-specific polyclonal sera or monoclonal antibodies. The Immunofluorescent assay (IFA) is a relatively cheap and fast technique for detecting IBV antigen in chickens, eggs, organ culture and cell culture. The IFA is group-specific when using polyclonalanti-IBV serum or groupspecific Mabs. When using type specific Mabs, the IFA can be a type-specific test (De Wit et al., 1995). The specificity of IFA can 
be improved by using Mabs instead of hyperimmune anti-IBV serum (Yagyu and Ohta, 1990; De Wit et al., 1995). Protection of the epithelium by reducing storage time (at low temperatures) between sampling and fixation will also improve the specificity of the IFA. The IFA can also be used for detection of IBV antigen in embryonated eggs, cellcultures, and organ culture (AbdelMoneim et al., 2009; Yagyu and Ohta, 1990). The immunoperoxidase assay (IPA) is a staining technique with a comparable sensitivity to that of IFA. After fixation and embedding of sections of organs or tissues, an anti-IBV specific peroxidase-labelled conjugate binds with and stains the antigen in the sample, after addition of the substrate and chromogen (Abdel-Moneim et al., 2009). Advantages of IPA compared to IFA are, that IPA allows evaluation of antigen- bearing cells as well as general tissue morphology. Also, evaluation of the slides can be done in day-light using a normal microscope, and storage of the slides is easy because of the stability of the staining, in contrast with IFA, where the staining fades when not stored dark and frozen. Disadvantages of IPA compared to IFA are that the technique is more laborious, takes a few days and is sensitive to non-specific background staining by endogenous peroxidase that is naturally present in the sample. This endogenous peroxidase has to be removed during the process of performing the IPT.

\section{Group-specific tests}

\section{Agar-gel precipitation test (AGPT)}

The test is very cheap, fast and requires few laboratory facilities. Although the test has an image of poor sensitivity, the published data using the test directly on organs suggest that it is not lower than that of recent techniques when used directly on organs. Another application of the AGPT is for confirmation of the presence of IBV in inoculated eggs (allantoic fluid or CAM)(Alexander and Gough, 1977; Gelb et al., 1981). In this situation, the sensitivity will be increased due to the replication of the virus. For this test, two holes are punched in an agar gel and known IBV antigen and sera from suspect birds are allowed to migrate through the gel. For best results, several antisera or an antiserum at different dilutions should be used to prevent false negative results caused by imbalance of the antigen:antiserum ratio (Lohr, 1981). An interaction between the antigen and any antibodies specific for IBV in the gel, results in precipitation of the antigen, which shows up as a visible line of identity in the gel. With this test, inclusion of a positive control serum adjacent to the well with test serum is important to be able to differentiate non-specific precipitation bands from IBVspecific bands (Woernle, 1966). Because of its ability to differentiate non-specific from specific reactions, the AGPT has a high specificity, although the precipitation lines for IBV are more difficult to read then for other agents like Gumboro or Newcastle virus.

\section{ELISA}

Reports of indirect ELISAs show them to be group specific (Garcia and Bankowski, 1981; Marquardt et al., 1981; Zellen and Thorsen, 1987; Perrotta et al., 1988; Karaca et al., 1990; Karaca and Naqi, 1993; De Wit et al., 1997). Antibodies can first be detected by ELISA within a week after vaccination or infection (Marquardt et al., 1981; Mockett and Darbyshire, 1981; Hawkes et al., 1983; Monreal et al., 1985; De Wit et al., 1997, 1998). Because of the short period between infection and the detection of the first antibodies by ELISA, the first of paired sampling must be done at the first signs of IBV, which usually appear between 18 and 36 $\mathrm{h}$ after infection (Cavanagh and Naqi, 1997). If the first sampling is not done in time, seroconversion can be missed. Specific IgM is only present temporarily after an infection or 
vaccination (Gillette, 1974; Mockett and Cook, 1986; Martins da Silva et al., 1990, 1991; Bhattacharjee et al., 1995; De Wit et al., 1998). Therefore, its detection is indicative for a recent infection or vaccination. However, the reports regarding IgM detection after IBV vaccination and infection are limited and partly conflicting. Therefore, more data collected under different conditions are needed before $\operatorname{IgM}$ detection techniques are suitable for use in the field.

\section{Serotype-specific tests}

Serotype-specific tests for detection of antibodies against IBV differentiate between antibodies induced by strains of different serotypes.

\section{Virus Neutralisation test (VNT)}

The VNT is the gold standard test for the detection of IBV serotype-specific antibodies. The test is by far the most accurate method available for differentiating between IBV serotypes as well as for confirming the identity of new ones. The specificity is very high after a single IBV inoculation (Marquardt et al., 1981; Gelb and Killian, 1987; Karaca and Naqi, 1993; De Wit et al., 1997). Cross-reactions can occur after multiple contacts with different IBV, although some studies also report low cross reactions after repeated inoculations with the same serotypes (Gelb and Killian, 1987; Karaca and Naqi, 1993). To perform the test it is necessary to have a culture of each IB virus of interest as well as monospecific antiserum to each one. These specific antisera are veryimportant if accurate differentiation of the serotypes is to be achieved. Each one is prepared by inoculating intranasally a group of SPF chickens with one of the IBV serotypes of interest. Blood is collected from the chickens 3 to 4 weeks later and the serum obtained from this blood contains serotype specific antibodies to the IB virus inoculated. The virus neutralisation test (VNT) is rarely used for routine diagnosis because it is relatively expensive and laborious.

\section{Haemagglutination inhibition test (HI)}

The first haemagglutination inhibiting antibodies are usually detected between 1 and 2 weeks after infection (Gough and Alexander, 1978; Timms et al., 1980; Macdonald et al., 1981; King and Hopkins, 1983; Brown and Bracewell, 1988; Muneer et al., 1988; De Wit et al., 1997). The HI-test is like the VNTa serotype-specific test when used to detect antibodies after a single inoculation with IBV. Although the correlation between both test systems is high under these circumstances, the specificity of the $\mathrm{HI}$ is considered to be lower than that of the VNT (King and Hopkins, 1983; Gelb and Killian, 1987; De Wit et al., 1997). The serotype-specificity of the HI-test is much lower following re-infection with IBV, especially when the second or subsequent serotype is heterologous (King and Hopkins, 1983; Gelb and Killian, 1987; Brown and Bracewell, 1988; De Wit et al., 1997). Sequential inoculation with IBV can induce antibodies that react in HI test with serotypes to which the birds had not been exposed.

\section{ELISA}

A new approach of producing serotypespecific tests was tried by using serotype specific Mabs as blocking agent in two blocking ELISAs (Karaca and Naqi 1993). Whereas the results after primary inoculation seemed to be serotype specific, heterologous cross reactions were detected by both the blocking ELISAs after a secondary inoculation with the homologous virus. Many studies have compared the performance of two or more serological tests. Due to the many variations in experimental conditions, 
test performance and kind of antibodies that are detected by the different tests, different results are reported. But generally, antibodies can first be detected by ELISA, followed by AGPT and HI-test, and last by VNT (Marquardt et al., 1981; Mockett and Darbyshire, 1981; Hawkes et al., 1983; Monreal et al., 1985; De Wit et al., 1997, 1998).

\section{Detection of IBV genome}

Techniques that detect all or part of the IBV genome may be used for IBV detection. Although one and two-step procedures are reported, the detection of genomic RNA is usually a three step procedure. The first step is replication of the virus from the (field) sample using embryonated eggs or organ culture. Subsequently, the genomic RNA is translated by reverse transcriptase (RT) into cDNA and multiplied many times by polymerase chain reaction (PCR).

\section{Reverse transcriptase polymerase chain reaction (RT-PCR)}

A technique increasingly used is the reverse transcriptase polymerase chain reaction (RTPCR) (Zwaagstra et al., 1992; Jackwood et al., 1997; Sylvester et al., 2003a, b).This method has been applied directly to material from infected chickens or after preliminary amplification of the virus in embryonated eggs because the sensitivity of the RT-PCR is usually low when performed directly on organs (Lin et al., 1991a, b). Therefore, IBV is often first multiplied in embryonated eggs or organ culture before the RT-PCR is performed. A 40-cycle PCR is used to detect the $\mathrm{N}$ protein gene of IBV in tracheal tissue extracts after experimental infection of chickens with a number of IBV types. Virus was detected in 75-100\% of tracheas collected at day 3 after inoculation, somewhat more than by immunoperoxidase staining of tracheal sections. Nested PCRs, in which some of the DNA produced in the first PCR is used in a second PCR using two further oligonucleotides, are considerably more sensitive than a single PCR. Nested PCR was used to amplify part of the S1 protein gene using RNA extracted from mouth swabs taken from broilers in the field. The type(s) of IBV present is determined by inclusion of several genotype specific oligonucleotides in the nested step. The additional sensitivity of the nested PCR permitted detection not only of major IBV infections but also of minor ones. The RT-PCR product is to be identified as originating from IBV by another technique such as sequencing (Zwaagstra et al., 1992), restriction enzyme fragment length polymorphism (RFLP) (Song et al., 1998), or hybridisation (Kwon et al., 1993). The genotype of IBV can be determined either by use of genotype- specific oligonucleotides or by sequencing the product. If sequencing is to be used, then "universal" oligonucleotides can be used in the RT-PCR (i.e., oligonucleotides designed to work with many, if not all, types of IBV.

\section{Restriction enzyme fragment length polymorphism (RFLP)}

After amplification of cDNA of the target gene by PCR and purification by electrophoresis, the PCR product is digested with restriction enzymes that cut cDNA into fragments at certain highly specific cleavage sites. The RFLP patterns are then compared with patterns of representatives of known serotypes. This test can provide a fast diagnosis, including typing of the virus (Lin et al., 1991a). However, cleavage sites of enzymes used in RFLP are not related and cannot be translated to biological or antigenic function and serotype can be high, but as reported, different isolates typed by RFLP as belonging to the same genotype, can be of different serotypes or protectotypes (Kwon et 
al., 1993; Montassier et al., 2008). Therefore, it is recommended that where there is suspicion in the field that the RFLP-genotype of recent isolates does not provide accurate information about the true antigenic nature of IBV isolates, conventional testing and especially in vivo studies are also used(Jia et al., 1995; Keeler et al., 1998; Hein et al., 1998).

\section{Rnase T1 fingerprinting analysis}

After multiplication of IBV, extracted and purified viral RNA is digested with ribonuclease (RNase) T1, resulting in oligonucleotides. After staining, the oligonucleotides are resolved on twodimensional gel electrophoresis, resulting in a fingerprint of the genome. The finger print can be compared with fingerprints of known strains.

\section{Sequencing}

Sequencing and subsequent comparison of the amino acid sequences of viral proteins is a very useful instrument to help locating conserved domains in proteins that might be essential for their structure and function and for epidemiological studies (Zulperi et al., 2009; Abro et al., 2012; Binnsetal., 1986; Boursnell et al., 1987; Zwaagstra et al., 1992). Based on sequence data, aphylogenic tree can be made, revealing the genomic relatedness between different strains. However, it must be remembered that the place of a certain strain in a phylogenic tree can differ depending on the genotyping techniques used, or on which part of the genome is analysed (Kusters et al., 1990; Zwaagstra et al., 1992). Sequence data only provide information about the primary structure (sequence of amino acids) of the protein. Detected differences in sequence of two strains cannot be translated to differences in antigenicity or biological function. Also the occurrence of recombinations between different IBV strains hampers the translation of data of a genotype to a serotype or protectotype.

In conclusion, infectious bronchitis is one of the most important poultry diseases in the world and since its first identification, the poultry industry has suffered a growing number of emerging IBV serotypes and quickly diagnosing it is critical for control of this highly infectious virus. Rapid and reliable detection and confirmation of IB is important to help limit economic losses and contain the disease. Conventional detection assays such as virus neutralization and virus isolation have been used extensively, but, due to lack of sensitivity and specificity of serological assays and laborious nature of virus isolation methods, these assays have gradually been replaced by the new sensitive and specific assays such as RT-PCR, RFLP, sequencing and qRT-PCR that enable rapid genotyping and identification of new IBV strains. $\mathrm{N}$

\section{References}

Abdel-Moneim AS, Zlotowski P, Veits J, Keil GM and Teifke JP. 2009. Immunohistochemistry for detection of avian infectious bronchitis virus strain M41 in the proventriculus and nervous system of experimentally infected chicken embryos. Virology Journal, 6:15.

Abro SH, Renstrom LHM, Ullman K et al., 2012. Emergence of novel strains of avian infectious bronchitis virus in Sweden. Veterinary Microbiology, 155(2-4): 237-246.

Adzar A, Gough RE, Haydon D, Shaw K, Britton P and Cavanagh D. 1997. Molecular analysis of the 793/B serotype of infectious bronchitis virus in Great Britain. Avian Dis., 26:625.

Alexander DJ and Gough RE. 1977. Isolation 
of avian infectious bronchitis virus from experimentally infected chickens, Research in Veterinary Science, 23(3): 344-347.

Ariaans MP, Matthijs MGR, van Haarlem D et al., 2008. The role of phagocytic cells in enhanced susceptibility of broilers to colibacillosis after infectious bronchitis virus infection. Veterinary Immunology and Immunopathology, 123(3-4):240 250.

Arshad SS. 1993. A study on two Malaysian isolates of infectious bronchitis virus [Ph.D. thesis], UniversitiPertanian Malaysia.

Arshad SS. 2006. Infectious bronchitis. in Diseases of Poultry in South East Asia, M. Zamri-Saad, Ed., UniversitiPutra Malaysia Press, Serdang, Malaysia, pp. 199-206.

Beaudette F and Hudson C. 1937. Cultivation of the virus of infectious bronchitis. Journal of the American Veterinary Medical Association, 90:51-60.

Bhattacharjee PS, Carter SD, Savage CE and Jones RC. 1995. Re-excretion of infectious bronchitis virus in chickens induced by cyclosporin. Avian Pathology, 24: 435- 441.

Binns MM, Boursnell MEG, Tomley FM and Brown TDK. 1986. Comparison of the spike precursor sequences of coronavirus IBV strains M41 and 6/82 with that of IBV Beaudette. Journal of General Virology, 67:2825-2831.

Boltz DA, Nakai M, Bahra JM. 2004. Avian infectious bronchitis virus: A possible cause of reduced fertility in the rooster. Avian Dis., 48:909-915.

Boroomand Z, Asasi K and Mohammadi A. 2012. Pathogenesis and tissue distribution of avian infectious bronchitis virus isolate IRFIBV32 (793/B serotype) in experimentally infected broiler chickens. The Scientific World Journal, 2012, Article ID
402537, 6 pages.

Boursnell MEG, Brown TDK, Foulds IJ, Green PF, Tomley FM and Binns MM. 1987. Completion of the Sequence of the Genome of the Coronavirus Avian Infectious Bronchitis Virus. J. Gen. Virol., 68: 57-77.

Brown AJ and Bracewell CD. 1988. Effect of repeated infections of chickens with infectious bronchitis viruses on the specificity of their antibody responses. Veterinary Record, 122: 207-208.

Capua I, Minta Z, Karpinska E, Mawditt K, Britton P, Cavanagh D and Gough RE. 1999. Co-circulation of four types of infectious bronchitis virus (793/B, 624/I, B1648 and Massachusetts). Avian Pathology, 28: 587- 592.

Cavanagh D and Gelb J Jr. 2008. Infectious Bronchitis. In: Diseases of Poultry, Saif YM, Fadl AM, Glisson JR, McDougald LR, Nolan LK and Swayne DE (Eds.). 12th Edn. Blackwell Publishing Professional, Ames, Iowa, USA. ISBN: 978-0-8138-0718-8, pp: 117-135.

Cavanagh D and Naqi S. 1997. Infectious bronchitis. In: Calnek BW, Barnes HJ, Beard CW, McDougald LR and Saif YM. (Eds.). Diseases of Poultry. 10th Ed. Iowa State University Press: Ames, IA. pp 511-526.

Cavanagh D, Mawditt $\mathrm{K}$, Britton $\mathrm{P}$ and Naylor CJ. 1999. Longitudinal studies of infectious bronchitis virus and avian pneumovirus in broilers using typespecific polymerase chain reactions. Avian Pathology, 28: 593- 605.

Cavanagh D, Naqi SA. 2003. Infectious bronchitis. In: Saif YM, ed. Disease of Poultry. Ames, Iowa: Iowa State UnivPr, pp 101-119.

Cavanagh D. (1983). Presence of viral antigens and antibody in the trachea of chickens infected with avian infectious bronchitis virus. Avian Pathol., 12: 331.

Cavanagh D. 2007. Coronavirus avian 
infectious bronchitis virus. Veterinary Research, 38(2): 281-297.

Cavanagh, D. (2005). Coronaviruses in poultry and other birds. Avian Pathol., 34: 439-448.

Chousalkar KK and Roberts JR. 2007. Ultrastructural study of infectious bronchitis virus infection in infundibulum and magnum of commercial laying hens. Veterinary Microbiology, 122(3-4): 223-236.

Chousalkar KK, Roberts JR and Reece R. 2007. Comparative histopathology of two serotypes of infectious bronchitis virus ( $\mathrm{T}$ andN1/88) in laying hens and cockerels. Poultry Science, 86(1):50 58.

Clarke JK, McFerran JB and Gay FW. 1972. Use of allantoic cells for the detection of avian infectious bronchitis virus. Archiv fur die GesamteVirusforschung, 36: 62-70.

Colwell WM and Lukert PD. 1969. Effects of avian infectious bronchitis virus (IBV) on tracheal organ cultures. Avian Diseases, 13: 888- 894.

Cong F, Liu X, Han Z, Shao Y, Kong X and Liu S. 2013. Transcriptome analysis of chicken kidney tissues following coronavirus avian infectious bronchitis virus infection. BMC Genomics, 14(1): 743.

Cook JK, Chester J, Baxendale W, Greenwood N, Huggins MB, Orbell SJ. 2001. Protection of chickens against renal damage caused by a nephropathogenic infectious bronchitis virus. Avian Pathol, 30:423-426.

Corse E and Machamer CE. 2003. The cytoplasmic tails of infectious bronchitis virus $\mathrm{E}$ and $\mathrm{M}$ proteins mediate their interaction. Virology, 312(1): 25-34.

Crinion RA and Hofstad MS. 1972. Pathogenicity of four serotypes of avian infectious bronchitis virus for the oviduct of young chickens of various ages. Avian Diseases, 16(2): 351-363.

Davies HA and Macnaughton MR. 1979. Comparison of the morphology of three coronaviruses. Arch. Virol., 59(1-2): 25-33.

De Wit JJ, Koch G, Kant A, and Roozelaar DJ van. 1995. Detection by immunofluorescent assay of serotypespecific and group-specific antigens of infectious bronchitis virus in tracheas of broilers with respiratory problems. Avian Pathology, 24:465-474.

De Wit JJ, Mekkes DR, Koch G and Westenbrink F. 1998. Detection of specific IgM antibodies to infectious bronchitis virus by an antibody-capture ELISA. Avian Pathology, 27: 155-160.

De Wit JJ, Mekkes DR, Kouwenhoven B and Verheijden JHM. 1997. Sensitivity and specificity of serological tests for detection of infectious bronchitis virus induced antibodies in broilers. Avian Pathology, 26:105-118.

De Wit JJ, Nieuwenhuisen-van Wilgen J, Hoogkamer A, vandeSande $\mathrm{H}$, Zuidam GJ and Fabri THF. 2011. Induction of cystic oviducts and protection against early challenge with infectious bronchitis virus serotype D388 (genotype QX) by maternally derived antibodies and by early vaccination. Avian Pathology, 40(5): 463-471.

Dhama K, Singh SD and Gowthaman V. 2011. Avian infectious bronchitis: An overview. Poult. Fortune, 11:35-49.

Gallardo RA, van Santen VL and Toro H. 2012. Effects of chicken anaemia virus and infectious bursal disease virusinduced immunodeficiency on infectious bronchitis virus replication and genotypic drift. Avian Pathology, 41(5): 451-458.

Garcia Z and Bankowski RA. 1981. Comparison of a tissue-culture virusneutralization test and the enzyme- 
linked immunosorbent assay for measurement of antibodies to infectious bronchitis. Avian Diseases, 25:121-130.

Gelb J and Killian SL. 1987. Serum antibody responses of chickens following sequential inoculations with different infectious bronchitis virus serotypes. Avian Diseases, 31: 513- 522.

Gelb JJr, Nix WA and Gellman SD. 1998. Infectious bronchitis virus antibodies in tears and their relationship to immunity. Avian Diseases, 42(2):364-374.

Gelb JJr, Perkins BE, Rosenberger JK and Allen PH. 1981. Serologic and crossprotection studies with several infectious bronchitis virus isolates from Delmarva-reared broiler chickens. Avian Diseases, 25: 655- 666.

Gillette KG. 1974. Avian infectious bronchitis: demonstration of serum IgG and IgM neutralising antibody by sucrose density gradient centrifugation and mercapto-ethanol reduction. Avian Diseases, 18: 515- 525.

Gough RE and Alexander DJ. 1978. Comparison of serological tests for the measurement of the primary immune response to avian infectious bronchitis virus vaccines. Veterinary Microbiology, 2:289-301.

Hawkes RA, Darbyshire JH, Peters RW, Mockett APA and Cavanagh D. 1983. Presence of viral antigens and antibody in the trachea of chickens infected with avian infectious bronchitis virus. Avian Pathology, 12:331-340.

Hein RG, Slacum G and Lynch P. 1998. In: Kalela, E.F. and Redmann, U.H. (Eds.), Proceedings of IInd International Symposium on Infectious Bronchitis and Pneumovirus infections in Poultry, Germany. pp: 87, 220.

Hofstad MS. 1984. In: Diseases of Poultry. Hofstad MS, Barnes HJ, Calnek BW, Reid WM and Yoder HW Jr. (Eds.), $8^{\text {th }}$ edn. Iowa State University Press,
Ames, IA, pp: 429.

Ignjatovic J, Sapats S. 2000. Avian infectious bronchitis virus. Rev Sci Tech, 19: 493503

Jackwood MW, Yousef NMH and Hilt DA. 1997. Further development and use of a molecular serotype identification test for infectious bronchitis virus. Avian Diseases, 41: 105-110.

Jia W, Karaca K, Parrish CR and Naqi SA. 1995. A novel variant of avian infectious bronchitis virus resulting from recombination among three different strains. Archives of Virology, 140: 259-271.

Jones BV and Hennion R M. 2008. The preparation of chicken tracheal organ cultures for virus isolation, propagation, and titration. Methods in Molecular Biology, 454:103-107.

Jones RC, Ambali AG. 1987. Re-excretion of an enterotropic infectious bronchitis virus by hens at point of lay after experimental infection at day old. Vet Rec., 120:617-620.

Karaca K and Naqi S. 1993. A monoclonal antibody blocking ELISA to detect serotype-specific infectious bronchitis virus antibodies. Veterinary Microbiology, 34: 249-257.

Karaca K, Naqi S, Palukaitis P and Lucio B. 1990. Serological and molecular characterization of three enteric isolates of infectious bronchitis virus of chickens. Avian Diseases, 34:899-904.

Keeler CLJr, Reed KL, Nix WA and Gelb JJr. 1998. Serotype identification of avian infectious bronchitis virus by RTPCR of the peplomer (S-1) gene. Avian Diseases, 42: 275- 284.

King DJ and Hopkins SR. 1983. Evaluation of the haemagglutination-inhibition test for measuring the response of chickens to avian infectious bronchitis virus vaccination. Avian Diseases, 27:100112. 
Kusters JG, Jager EJ, Niesters HGM and van der Zeijst BAM. 1990. Sequence evidence for RNA recombination in field isolates of avian coronavirus infectious bronchitis virus. Vaccine, 8:605-608.

Kwon HM, Jackwood MW, and Gelb JJr. 1993. Differentiation of infectious bronchitis virus serotypes using polymerase chain reaction and restriction fragment length polymorphism analysis. Avian Diseases, 37(1): 194-202.

Lin Z, Kato A, Kudou Y and Ueda S. 1991a. A new typing method for the avian infectious bronchitis virus using polymerase chain reaction and restriction enzyme fragment length polymorphism. Archives of Virology, 116(1-4):19-31.

Lin Z, Kato A, Kudou Y, Umeda K and Ueda S. 1991b. Typing of recent infectious bronchitis virus isolates causing nephritis in chicken. Archives of Virology, 120(1-2): 145-149.

Lohr JE. 1981. Diagnosis of infectious bronchitis (IB) by examination of tracheal mucus for IB- precipitating antigens. Avian Diseases, 25:10581064.

Loomis LN, Cunningham $\mathrm{CH}$, Gray ML and Thorp FJr. 1950. Pathology of the chicken embryo infected with infectious bronchitis virus. American Journal of Veterinary Research, 11(40): 245-251.

Lukert PD. 1965. Comparative sensitivities of embryonating chicken's eggs and primary chicken embryo kidney and liver cell cultures to infectious bronchitis virus. Avian Diseases, 9:308316.

Macdonald JW, Randall CJ, McMartin DA, Dagless MD and Gazdzinski P. 1981. Active and passive immunisation against nephritis induced by an avian infectious bronchitis virus. Avian
Pathology, 10:121-129.

Marquardt WW, Snyder DB and Schlotthober BA. 1981. Detection and quantification of antibodies to infectious bronchitis virus by enzyme-linked immunosorbent assay. Avian Diseases, 25:713-722.

Martins da Silva NR, Mockett APA and Cook JKA. 1990. A method for the rapid purification of serum $\operatorname{IgM}$ for the diagnosis of recent viral infections of chickens. Journal of Virological Methods, 29: 117-126.

Martins da Silva NR, Mockett APA, Barrett ADT and Cook JKA. 1991. IgM responses in chicken serum to live and inactivated infectious bronchitis virus vaccines. Avian Diseases, 35:470-475.

McMartin DA. 1993. Infectious bronchitis. In McFerran JB and McNulty MS. (Eds.), Virus Infections of Vertebrates. Virus Infections of birds, Amsterdam: Elsevier Science Publishers, 4:249-275.

Mockett APA and Cook JKA. 1986. The detection of specific IgM to infectious bronchitis virus in chicken serum using an ELISA. Avian Pathology, 15: 437446.

Mockett APA and Darbyshire JH. 1981. Comparative studies with an enzymelinked immunosorbent assay (ELISA) for antibodies to avian infectious bronchitis virus. Avian Pathology, 10:110.

Monreal G, Bauer HJ and Wiegmann J. 1985. Comparison of the enzyme-linked immunosorbent assay (ELISA), haemagglutination inhibition test and agar gel precipitation test for detection of antibodies to avian infectious bronchitis virus. Avian Pathology, 14:421- 434

Montassier MDFS, Brentano L, Montassier H J and Richtzenhain LJ. 2008. Genetic grouping of avian infectious bronchitis virus isolated in Brazil based on RTPCR/RFLP analysis of the S1 gene. 
Pesquisa Veterinaria Brasileira, 28(3):190- 194.

Muneer MA, Newman JA, Halvorson DA, Sivanandan V, Nagaraja KV and Coon CN. 1988. Efficacy of infectious bronchitis virus vaccines against heterologous challenge. Research in Veterinary Science, 45: 22- 27.

Otsuki K, Yamamoto $\mathrm{H}$ and Tsubokura M. 1979. Studies on avian infectious bronchitis virus (IBV) - I. Resistance of IBV to chemical and physical treatments. Archives of Virology, 60(1): 25-32.

Perrotta C, Furtek C, Wilson RA, Cowen BS and Eckroade RJ. 1988. A standardized enzyme-linked immunosorbent assay for infectious bronchitis virus: comparison with hemagglutination inhibition and virus-neutralization assays for measuring protective antibody levels in chickens. Avian Diseases, 32: 451- 460.

Pradhan HK, Mohanty GC and Verma KC. 1982. Isolation and characterisation of viral agents from the reproductive tract of young chicks. Indian J. Poult. Sci., 17: 143-148.

Schalk A and Hawn M. 1931. An apparently new respiratory disease of baby chicks. Journal of the American Veterinary Medical Association, 78:413-422.

Song CS, Lee YJ, Kim JH, Sung HW, Lee CW, Izumiya Y, Miyazawa T, Jang HK and Mikami T. 1998. Epidemiological classification of infectious bronchitis virus isolated in Korea between 1986 and 1997. Avian Pathology, 27: 409416.

Sylvester SA, Dhama K, Kataria JM, Rahul S and Mahendran M. 2005. Avian infectious bronchitis virus: A review. Indian J. Comp. Microbiol., Immunol Infect. Dis., 26: 1-14.

Sylvester SA, Kataria JM, Dhama K, Rahul S, Bhardwaj N and Tomar S. 2003b.
Purification of infectious bronchitis virus propagated in embryonated chicken eggs and its confirmation by RT-PCR. Indian J. Comp. Microbiol. Immunol. Infect. Dis., 24:143-147.

Sylvester SA, Kataria JM, Dhama K, Senthil Kumar N, NitinBharadwaj and Rahul S. 2003a. Detection of avian infectious bronchitis virus in infected allantoic fluid using $\mathrm{S} 1$ gene serotype specific RT-PCR. Ind. J. Comp. Microbiol. Immunol. Infect. Dis., 24: 39-42.

Timms LM, Bracewell CD and Alexander DJ. 1980. Cell mediated and humoral immune response in chickens infected with infectious bronchitis. British Veterinary Journal, 136: 349-356.

Verma KC and Malik BS, 1971. Isolation of infectious bronchitis virus of poultry in India. Indian Vet. J., 48:887-892.

Wadey CN and Faragher JT. 1981. Australian infectious bronchitis viruses: identification of nine subtypes by a neutralisation test. Research in Veterinary Science, 30:70-74.

Wilson L, Gage P and Ewart G. 2006. Hexamethylene amiloride blocks E protein ion channels and inhibits coronavirus replication. Virology, 353(2):294-306.

Winterfield RW and Hitchner SB. 1962. Etiology of an infectious nephritisnephrosis syndrome of chickens. American Journal of Veterinary Research, 23:1273-1279.

Winterfield RW, Thacker HL and Badylak SF. 1984. Effects of subtype variations in the Holland strain of infectious bronchitis virus when applied as a vaccine. Poultry Science, 63(2):246250.

Woernle H. 1966. The use of the agar-geldiffusion technique in the identification of certain avian virus diseases. The Veterinarian, 4: 17-28.

Yagyu K and Ohta S. 1990. Detection of 
infectious bronchitis virus antigen from experimentally infected chickens by indirect immunofluorescent assay with monoclonal antibody. Avian Diseases, 34(2):246-252.

Zellen GK and Thorsen J. 1987. Determination of the antigenic relationships among six serotypes of infectious bronchitis virus using the enzyme-linked immunosorbent assay and the serum neutralization test. Avian
Diseases, 31: 455-458.

Zulperi ZM, Omar AR and Arshad SS. 2009.

Sequence and phylogenetic analysis of $\mathrm{S} 1, \mathrm{~S} 2, \mathrm{M}$, and $\mathrm{N}$ genes of infectious bronchitis virus isolates from Malaysia. Virus Genes, 38(3): 383-391.

Zwaagstra KA, van der Zeijst BAM and Kusters JG. 1992. Rapid detection and identification of avian infectious bronchitis virus. Journal of Clinical Microbiology, 30: 79- 84.

\section{How to cite this article:}

Shekhar, S., S.B. Sudhakar, A. Kumar and Kumar, S. 2019. Approaches for Diagnosis of Avian Infectious Bronchitis. Int.J.Curr.Microbiol.App.Sci. 8(09): 539-553.

doi: https://doi.org/10.20546/ijcmas.2019.809.065 